\title{
Are Stock Markets and Foreign Exchange Markets Cointegrated? An Empirical Analysis
}

\author{
Fahmida Laghari ${ }^{1}$, Ye Chengang ${ }^{1}$ \\ ${ }^{1}$ University of International Business and Economics (UIBE) Beijing, China
}

*Corresponding Author: Fahmida Laghari, University of International Business and Economics (UIBE) Beijing, China

\begin{abstract}
This study aims to investigate long-run and short run relationship between stock market index and exchange rates along with interest rates and consumer price index. The study inspects empirical findings with autoregressive distributed lag (ARDL) model, error correction modelling technique, and Granger causality analysis using quarterly data ranging from the period 2002:q1 to 2016:q1. The empirical findings indicate long run equilibrium relationship between stock market index and exchange rates. The Granger causality analysis indicates unidirectional causality between exchange rates and stock market index, and identifies exchange rates Granger cause stock market index. The findings of the study conclude that there is a long run equilibrium relationship between stock market index and exchange rates. The Granger causality test finds that in case of Pakistan exchange rates Granger cause stock market index, thus supports the traditional approach.
\end{abstract}

Keywords: Stock market index, Exchange rates, Interest rates, Consumer price index

\section{INTRODUCTION}

Capital markets and foreign exchange markets play a dynamic role in economic and portfolio decisions ${ }^{[1]}$. Stock markets and foreign exchange markets significantly influence each other in longrun as well as short-run ${ }^{[2]}$. During crisis stock markets and foreign exchange markets fully impact or reflect each other. In a condition if stock prices and exchange rates are linked and exchange rates cause stock prices then crisis of stock markets can be prevented by controlling exchange rates ${ }^{[3]}$. This situation can be helpful for the developing countries to enhance foreign portfolio investment in their country. Likewise, in a condition when stock prices cause exchange rates then stock markets can be stabilized by authorities through fixing the domestic economic policies ${ }^{[4]}$. The relationship between stock markets and foreign exchange markets can be helpful for investors by utilizing any information or innovation of one market to predict the behavior of other market.

Considerable number of researches have been carried out on the relationship of stock market with foreign exchange market, for developed countries e.g., ${ }^{[5]},{ }^{[6]},{ }^{[7]}$, for developing countries e.g., ${ }^{[8]},{ }^{[9]}$, ${ }^{[10]},{ }^{[11]}$. On the other hand, significant number of studies have worked on the long run relationship between the stock markets/prices and exchange rates but fail to find such relationship e.g. ${ }^{[12]},{ }^{[13]},{ }^{[14]}$, ${ }^{[15]}$. In the context of Pakistan ${ }^{[16]}$ worked on the relationship between stock prices and exchange rates and find no long run relationship for Pakistan. Economists, policymakers, and foreign investors extensively influenced by, and got attention towards the relationship of stock markets/prices and exchange rates. On theoretical work fronts, there are two views for stock prices and exchange rates relationship. According to one view, flow-oriented models of exchange rates emphasis on trade balance or current account balance ${ }^{[17]}$. These models stress that change in exchange rates influence international desirability and hence affect output and real income. Also, as prices of stocks can be viewed as the present value of future cash flows of firms, they respond to exchange rate changes. Conversely, stock-oriented models of exchange rates ${ }^{[18]}$ and ${ }^{[19]}$ suggest that stock market innovations affect aggregate demand by the liquidity and wealth effects, ultimately impact demand of money ${ }^{[20]}$. A decline in stock prices reduce the wealth of domestic investor that consequently lead to lower money demand hence ensure lower interest rates. Afterwards, lower interest rates cause discourage of capital inflow, keeping other things constant, ultimately currency depreciates, and henceforth, may affect exchange rate dynamics due to movement of stock prices. 
The goal of this paper is to investigate empirical evidence on long-run as well as short-run relationship between stock market index and exchange rates along with interest rates and consumer price index. This paper uses quarterly data ranging from 2002:q1 to 2016:q1 for the economy of Pakistan. The paper uses autoregressive distributed lag (ARDL) technique, error correction modelling technique and Granger causality test for empirical testing.

The rest of the paper is arranged as follows: section two discusses the relevant literature, section three represents data, variables, and methodology, section four includes empirical results, and fifth section represent the concluding remarks.

\section{REVIEW OF RELATED Literature}

In a study by ${ }^{[21]}$ investigated long run relationship between stock prices and exchange rates for nine countries by applying cointegration technique. They observed no cointegration between stock prices and exchanges rates. But by including interest rates in the regression equation they find long-run relationship for six countries out of nine. A study by ${ }^{[22]}$ worked on long-run and short-run relationship between stock markets/prices and exchanges rates for Thailand and Indonesia from the period November 8, 1991 to December 26, 1997. They were fail to find long run relationship in cointegration analysis, however, successfully find bidirectional causality by Granger causality analysis.

In their analysis by ${ }^{[9]}$ examined the long-run relationship between stock prices and exchange rates from the period 1989 to 2003 on six emerging Asian economies. They find no cointegration between stock prices and exchange rates, but bidirectional causality was observed for Thailand, Korea, Malaysia, and Indonesia. They observed negative relationship between stock prices and exchange rates for all countries except Thailand.

A study by ${ }^{[23]}$ worked on Romania after 1997 exchange rate regime change using monthly data from the period January 1998 to September 2007. They worked on stock prices and exchange rates with other macroeconomic variables by using cointegration and innovation accounting techniques. They observed that cointegrating vectors are consistent with economic reasoning by showing positive relationship between money supply and stock prices and between nominal effective exchange rates and stock prices.

In their empirical analysis ${ }^{[24]}$ worked on daily data from the period 1993 to 2003 to observe the causal relationship between stock prices and exchange rates for Thailand and Malaysia. They applied cointegration test of ${ }^{[25]}$ to find long run relationship and ${ }^{[26]}$ procedure to find short run relationship. The study revealed that stock prices lead exchange rates for Thailand and support portfolio balanced approach for both pre and post financial crisis. While, the findings for Malaysia supported portfolio balanced approach only for the post financial crisis.

In a study by ${ }^{[27]}$ analyzed seven African countries to find the long-run relationship between stock prices and exchange rates. In the study vector autoregressive specification based cointegration analysis and impulse response function were applied. Their research findings observed long run relationship between stock prices and exchange rates in Ghana. Moreover, the impulse response function also find similar relationship for Ghana. The impulse response function observed declined stock returns due to induced shock of exchange rates for Nigeria, Kenya, Ghana, and Mauritius. On the other hand, the impulse response function observed increased stock returns due to induced shock of exchange rates for South Africa and Egypt.

In a study by ${ }^{[28]}$ worked on 12 OECD countries to find long run and short run relationship between stock prices and exchange rates. They applied linear and non-linear Granger causality test with vector error correction model and methodology of bound testing. They found long run relationship for 7 countries. Moreover, the Granger causality test for non-linear causal relationship indicated both unidirectional and bidirectional causality in stock prices and exchange rates.

In their study by ${ }^{[29]}$ used monthly data to find relationship between foreign exchange market and stock market for Bangladesh. They applied Granger causality test on the sub samples of the data and find no causality between foreign exchange markets and stock markets.

In an empirical analysis by ${ }^{[30]}$ focused on multi-scale stock prices and exchange rates relationship for eight Asian economies. They used cross-correlation and wavelet correlation with quantile regression techniques. Study observed negative correlation between stock prices and exchange rates. The quantile 
regression results revealed that coefficient are more negatively inclined when exchange rates are at high levels.

A study by [31] examined South Asian countries Pakistan, India, Bangladesh and Sri Lanka. They worked on long run and short run relationship between stock prices and exchange rates. Study used monthly data ranging from January 2008 to December 2012 by applying techniques of cointegration, error correction and Granger causality test. For Pakistan and India no long as well as short run relationship observed. Whereas, long run relationship observed for Bangladesh and Sri Lanka but no short run relationship observed between stock prices and exchange rates.

\section{DATA, VARIAbles, AND Methodology of THE RESEARCH}

\subsection{Data and Variables}

The data has been taken from the Economist Intelligence Unit (EIU) database services. The quarterly data for the variables stock market index, exchange rates, interest rates, and consumer price index ranging from 2002:q1 to 2016:q1 has been used in the study. The variables series for the study has been adjusted to match the frequency and to control for the missing values. The quarterly selected series for the variables under study has provided comprehensive insight about the long run and short run dynamics as compare to the yearly data. The variables used in the study are: stock market index, exchange rates, interest rates, and consumer price index. All the variables are denominated in the local currency units. The exchange rate is measured in unit of PKR/USD.

\subsection{Methodology of the Study}

The main focus of the study is to find out the dynamic long run and short run relationship between stock market index and exchange rates along with the interest rates and consumer price index for the period 2002:q1 to 2016:q1. If long run relationship be observed, then short run relationship is obvious. Existing literature evident several methods to check long run equilibrium relationship among variable of interest in time series research. Prior researches have adopted methods like; ${ }^{[32]}{ }^{[33]},{ }^{[34]}$, and ${ }^{[25]}$ based on maximum likelihood estimation. Moreover, literature has also used ${ }^{[35]}$ fully modified OLS procedure. These discussed techniques lack in power and also can not properly handle small samples. Moreover, these methods require data or variable in the system be in order of I(1). Keeping these shortcomings of discussed tests in consideration our study uses more robust autoregressive distributed lag (ARDL) ${ }^{[36]}$ procedure to find cointegration among variables of the study.

The main advantage of using (ARDL) over other techniques is that, there is no need of stationary properties of the analysis variables in the sample. This technique also allows inference for long-run estimates and can be analyzed significantly for greater number of variables in contrast to other models of vector autoregressive (VAR) technique.

Before applying ARDL model the unit root test is applied. In that regard study uses augmented Dickey-Fuller test. Augmented Dickey Fuller (ADF) test is applied to make series stationary. The ADF test is based on the unit root test of Dickey-Fuller extension of extra lagged difference that is helpful in eliminating the autocorrelation in the lags of dependent variable. The ADF test is based on (AIC) Akaike Information Criterion or the Schwartz Bayesians Information Criterion (SBC) ${ }^{[37]}$.The ADF test-statistics is:

$$
\Delta Y_{t}=a_{0}+\delta x_{t-1}+\sum_{i=1}^{\rho} \beta_{i} Y_{t-1}+\varepsilon_{t}
$$

The lags of the $\Delta \mathrm{y}_{\mathrm{t}}$ will settle the dependent variable against any dynamic structure, by settling the autocorrelation in $\varepsilon_{\mathrm{t}}$. The null hypothesis under this test is: $\delta=0$. The unit root test is essential in order to avoid any sign of spurious regression. Because bound test of ARDL is based on the assumption that analysis variables are either I(0) or I(1) order [38]. The computed value of F-statistics will be invalid in the case if the order of the variables of analysis is found $\mathrm{I}(2)$.

After identification of $\mathrm{I}(0)$ or I(1), the next step is to apply the ARDL model. The study has used following model to test the long-run equilibrium relationship between stock market index and exchange rates with macroeconomic variables.

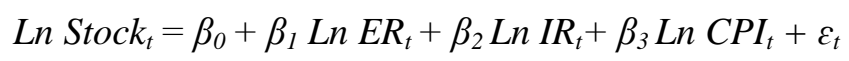

Where 


$$
\begin{aligned}
& \text { Stock = Stock Market Index } \\
& \text { ER = Exchange Rates } \\
& \text { IR= Interest Rates } \\
& \text { CPI = Consumer Price Index }
\end{aligned}
$$

The model two of the study is estimated without macroeconomic variables as follows:

$$
\text { Ln Stock }{ }_{t}=\beta_{0}+\beta_{1} \operatorname{Ln} E R_{t}+\varepsilon_{t}
$$

Where

$$
\begin{aligned}
& \text { Stock }=\text { Stock Market Index } \\
& \text { ER }=\text { Exchange Rates }
\end{aligned}
$$

The next stage is the estimation of the error correction equation. The error correction model (ECM) technique uses cointegrated variables lagged levels and differenced combination. ECM can be written as:

$$
\Delta y_{t}=\alpha_{1} \Delta x_{t}+a_{2}\left(y_{t-1}-\phi x_{t-1}\right)+\varepsilon_{t}
$$

Here $\left(y_{t-1}-\phi x_{t-1}\right)$ is error correction term and $\phi$ is cointegrating coefficient. The equation shows if $\mathrm{y}_{\mathrm{t}}$ and $\mathrm{x}_{\mathrm{t}}$ are cointegrated with $\phi$ then the series $\left(y_{t-1}-\phi x_{t-1}\right)$ would be with the order $\mathrm{I}(0)$ even with the presence of $\mathrm{I}(1)$ constituents.

The next step is to find the stability of the short-run and long-run coefficient with the help of cumulative sum (CUSUM) test and cumulative sum of squares (CUSUMSQ) test. The CUSUM and CUSUMSQ statistics are plotted against break points, and are recursively updated. The null hypothesis for the regression coefficients is considered structurally stable and fails to reject if the CUSUM and CUSUMSQ statistics stay under the critical bonds at the significance level of five percent.

Finally, study also applies Granger causality test in order to check the direction of causality among the analysis variables. The Granger causality test is applied on the differenced series after making series stationary. This is based on [39] causality definition where one time series Granger causes other time series. The causal relationship between two series for example A and B can be done through the following bivariate autoregression [39].

$$
\begin{aligned}
& A_{t}=a_{0}+\sum_{k=1}^{n} \alpha_{k} B_{t-k}+\sum_{k=1}^{n} \beta_{k} A_{t-k}+\varepsilon_{A, t} \\
& B_{t}=\delta_{0}+\sum_{k=1}^{n} \delta_{k} B_{t-k}+\sum_{k=1}^{n} \theta_{k} A_{t-k}+\varepsilon_{B, t}
\end{aligned}
$$

Here $\alpha_{0}$ and $\delta_{0}$ are constant and $\alpha_{\mathrm{k}}, \delta_{\mathrm{k}}$, and $\theta_{\mathrm{k}}$ are parameters and $\varepsilon_{\mathrm{A}, \mathrm{t}}$ and $\varepsilon_{\mathrm{B}, \mathrm{t}}$ are disturbance terms.

\section{EMPIRICAL ANALYSIS}

\subsection{Descriptive Statistics}

Descriptive statics describes features of the sample. Mean and median represent central tendency, and standard deviation denotes measure of dispersion. Skewness displays information about measure of asymmetry of random variable for probability distribution. Kurtosis signifies information about the tail of probability distribution for the random variable. Jarque-Bera test inspects normality of the data.

Table1. Descriptive Statistics

\begin{tabular}{|l|l|l|l|l|}
\hline & $\begin{array}{l}\text { Stock Market } \\
\text { Index }\end{array}$ & Exchange Rates & Interest Rates & $\begin{array}{l}\text { Consumer Price } \\
\text { Index }\end{array}$ \\
\hline Mean & 4.0194 & 1.8778 & 1.0073 & 2.0621 \\
\hline Median & 4.0500 & 1.9000 & 1.0200 & 2.0700 \\
\hline Maximum & 4.5400 & 2.0300 & 1.1700 & 2.3100 \\
\hline Minimum & 3.2500 & 1.7600 & 0.7000 & 1.8100 \\
\hline Std. Dev. & 0.3283 & 0.1002 & 0.1303 & 0.1766 \\
\hline Skewness & -0.4440 & 0.0991 & -0.9716 & -0.0114 \\
\hline Kurtosis & 2.8440 & 1.3376 & 3.1393 & 1.4890 \\
\hline Jarque-Bera & 1.9308 & 6.6564 & 9.0154 & 5.4236 \\
\hline Probability & 0.3808 & 0.0358 & 0.0110 & 0.0664 \\
\hline Observations & 57 & 57 & 57 & 57 \\
\hline
\end{tabular}


Table (1) represents descriptive statistics for variables stock market index, exchange rates, interest rates and consumer price index. The mean and median values for stock market index are 4.0194 and 4.0500 respectively. The maximum value for stock market index is 4.5400 with minimum value of 3.2500. The standard deviation is 0.3283 with skewness and kurtosis values of -0.4440 and 2.8440 respectively. The value for Jarque-Bera is 1.9308 with probability of 0.3808 . The mean value of exchange rates is 1.8778 with median 1.9000 . The maximum and minimum values for the variable exchange rates are 2.0300 and 1.7600 respectively. The standard deviation is 0.1002 with skewness value of 0.0991 . The kurtosis shows value of 1.4406 and Jarque-Bera test is 6.6564 with the p-value of 0.0358 . The mean value of variable interest rates is 1.0073 with median value of 1.0200 . The variable interest rate shows maximum value of 1.1700 with minimum value of 0.7000 .The standard deviation is 0.1303 with skewness and kurtosis -0.9716 and 3.1393 respectively. The Jarque-Bera test value is 9.0154 with P-value of 0.0110 . The mean value for variable consumer price index is 2.0621 with median, maximum, and minimum values $2.0700,2.3100$, and 1.8100 respectively. The standard deviation value is 0.1766 and values for skewness and kurtosis are -0.0114 and 1.4890 respectively. The value of Jarque-Bera test for variable consumer price index is 5.4236 with probability of 0.0664 .

\subsection{Stationary Test}

Study uses augmented Dickey-Fuller (ADF) test on time series variables in levels and differenced forms to test for unit root. The ADF test checks for stationary of four variables, stock market index, exchange rates, interest rates and consumer price index. Table (2) represents results for ADF test of all the time series analysis variables in the study. The ADF test analysis indicates the acceptance of null hypotheses of non-stationary for all the variables at levels. Moreover, ADF test shows all variables are stationary at first difference as shown in table (2).

Table2. Results for the ADF-augmented Dickey Fuller test

\begin{tabular}{|l|l|l|}
\hline & ADF-test values at levels & ADF-test values at first difference \\
\hline STOCK & -1.9665 & -1.9665 \\
\hline ER & -0.1965 & -0.1965 \\
\hline IR & -2.4852 & -2.4852 \\
\hline CPI & -0.5241 & -0.5241 \\
\hline $1 \%$ Critical Value & -3.5547 & -3.5572 \\
\hline $5 \%$ Critical Value & -2.9157 & -2.9167 \\
\hline $10 \%$ Critical Value & -2.5953 & -2.5958 \\
\hline Notes: STOCK is stock market index, ER is exchange rates, CPI is consumer price index, IR is interest rate. \\
\hline
\end{tabular}

\subsection{Autoregressive Distributed Lag Model (ARDL) Bound Test for Cointegration}

Study uses ARDL bound testing technique to investigate the long run cointegration under the null hypothesis of no cointegration. ARDL model obliges a prior knowledge to select the lag order. The study uses Akaike info criterion (AIC) to select the order of distributed lag on dependent variable and regressors. The maximum lag length based on AIC preference is set to lag 2 for the quarterly time series data of study. The regression results of the ARDL bound test based on F-statistics for testing the joint significance level of the lagged level are stated in table (3).

Table3. ARDL bound test results for long run association

\begin{tabular}{|l|l|l|l|}
\hline Model (effect/cause) & F-statistics & Probability & Remarks \\
\hline F(STOCK/ER, CPI, IR) & 2.9514 & 0.0312 & No cointegration \\
\hline F(STOCK/ER) & 4.9165 & 0.0115 & cointegration \\
\hline $\begin{array}{l}\text { Notes: STOCK is stock market index, ER is exchange rates, CPI is consumer price index, IR is interest rate. } \\
\text { The critical values of F-statistics are based on Pesaran et al., (2001) 5 per cent critical bounds. }\end{array}$
\end{tabular}

Table (3) exhibits the results for model (2) and model (3). The results for ARDL model (2) show low F-values compared to the critical values, and results for ARDL model (3) show high F-values as compared to the critical values [40]. The significant results for model (3) imply that there is a long-run equilibrium relationship between stock market index and exchange rates. The selected ARDL models are robust in terms of standard diagnostic tests with probability of F-statistics above 5 percent level of significance, as shown in table (4) and table (5). 


\subsection{Long-Run and Short-Run Coefficients Estimation}

After detecting the long-run relationship from ARDL bound testing analysis for the relationship of stock market index and exchange rates, next step is to estimates the long-run elasticities of the longrun equation of ARDL model. Table (4) represents results for long-run coefficient estimates. In table (4) column 3 the relationship between stock market index and exchange rates is significant and positive. The findings of results imply that over the long run, there is positive impact of dollar exchange rate on stock market index. This imply that $1 \%$ increase in exchange rate will increase stock market index by $0.27 \%$. The findings of results also indicate that there is a positive effect of exchange rates on stock market index.

Table4. Regression results for Long run association

\begin{tabular}{|c|c|c|c|c|}
\hline Variables & F(ST/ER, CPI, IR) & \multicolumn{3}{|l|}{ F(ST/ER) } \\
\hline Intercept & $0.1539 \quad(0.27)$ & \multicolumn{3}{|c|}{$0.0017 \quad(0.01)$} \\
\hline STOCK $(-1)$ & $-0.1493^{*}(-1.73)$ & \multicolumn{3}{|c|}{$-0.1181 * * *(-3.14)$} \\
\hline $\mathrm{ER}(-1)$ & $0.2073 \quad(0.31)$ & \multicolumn{3}{|c|}{$0.2701^{* *} \quad(2.38)$} \\
\hline CPI(-1) & $0.0870 \quad(0.17)$ & \\
\hline INTEREST(-1) & $-0.0439 \quad(-0.55)$ & \multicolumn{3}{|l|}{+2} \\
\hline R-squared & 0.4145 & \multicolumn{3}{|l|}{0.2782} \\
\hline Adjusted R-squared & 0.2431 & \multicolumn{3}{|l|}{0.1860} \\
\hline Akaike info criterion & -2.9606 & \multicolumn{3}{|l|}{-2.9736} \\
\hline Schwarz criterion & -2.4817 & \multicolumn{3}{|l|}{-2.7157} \\
\hline F-statistic & 2.4186 & \multicolumn{3}{|l|}{3.0197} \\
\hline Prob(F-statistic) & 0.0177 & \multicolumn{3}{|l|}{0.0140} \\
\hline \multicolumn{5}{|c|}{ Diagnostic tests for long run association } \\
\hline Model & Test & \multicolumn{2}{|l|}{ Parameters } & Probability \\
\hline \multirow[t]{4}{*}{ F(STOCK/ER, CPI, IR) } & \multirow{2}{*}{$\begin{array}{ll}\text { Breusch-Godfrey } & \text { Serial } \\
\text { Correlation LM Test } & \end{array}$} & F-statistic & 1.5059 & 0.2344 \\
\hline & & Obs*R-squared & 3.8712 & 0.1443 \\
\hline & \multirow[t]{2}{*}{ ARCH Test } & F-statistic & 0.4696 & 0.6280 \\
\hline & & Obs*R-squared & 0.9779 & 0.6132 \\
\hline \multirow[t]{4}{*}{ F(STOCK /ER) } & \multirow{2}{*}{$\begin{array}{ll}\text { Breusch-Godfrey } & \text { Serial } \\
\text { Correlation LM Test } & \end{array}$} & F-statistic & 1.0892 & 0.3452 \\
\hline & & Obs*R-squared & 2.4935 & 0.2874 \\
\hline & \multirow[t]{2}{*}{ ARCH Test } & F-statistic & 2.7045 & 0.0769 \\
\hline & & Obs*R-squared & 5.1696 & 0.0754 \\
\hline
\end{tabular}

The table (5) shows results for estimated error correction model (ECM) or short run relationship of the selected ARDL model. The findings of results for estimated coefficient of ECM is negative, as expected, and significant at one percent significance level. The error correction term denotes speed of adjustment towards the equilibrium over the long run. The coefficient of ECT (-1) for model 3 is -0.12 as shown in table (5) column 2 . These results imply that $12 \%$ disequilibrium of previous quarter's shock can be adjusted in the current quarter. The study also included the short-run diagnostic tests, which clearly indicates that the results are highly robust. Two stability tests cumulative sum of recursive residuals (CUSUM) and the cumulative sum of square of recursive residuals (CUSUMSQ) are also conducted in the study. The plots of stability test for (CUSUM) and (CUSUMSQ) are presented in figure (1) and figure (2). The findings of both plots for (CUSUM) and (CUSUMSQ) displays that the model (3) is structurally stable.

Table5. Regression results of short run association for model (F (ST/ER))

\begin{tabular}{|l|l|}
\hline Variables & F(STOCK /ER) \\
\hline Intercept & $0.0339 * *(3.07)$ \\
\hline $\mathrm{D}($ STOCK $(-1))$ & $-0.0457 \quad(-0.32)$ \\
\hline $\mathrm{D}($ STOCK $(-2))$ & $0.0416 \quad(0.29)$ \\
\hline $\mathrm{D}(\mathrm{ER}(-1))$ & $-1.8008^{* *}(-2.47)$ \\
\hline $\mathrm{D}(\mathrm{ER}(-2))$ & $-0.3489 \quad(-0.48)$ \\
\hline ECT $(-1)$ & $-0.1172 * * *(-3.15)$ \\
\hline R-squared & 0.2767 \\
\hline Adjusted R-squared & 0.2013 \\
\hline Akaike info criterion & -3.0085 \\
\hline
\end{tabular}


Are Stock Markets and Foreign Exchange Markets Cointegrated? An Empirical Analysis

\begin{tabular}{|c|c|c|c|}
\hline Schwarz criterion & \multicolumn{3}{|l|}{-2.7875} \\
\hline F-statistic & \multicolumn{3}{|l|}{3.6725} \\
\hline Prob(F-statistic) & \multicolumn{3}{|l|}{0.0068} \\
\hline \multicolumn{4}{|c|}{ Diagnostic tests of short run association for model F (STOCK /ER) } \\
\hline Test & \multicolumn{2}{|l|}{ Parameters } & Probability \\
\hline \multirow[t]{2}{*}{ Breusch-Godfrey Serial Correlation LM Test } & F-statistic & 1.1693 & 0.3196 \\
\hline & Obs*R-squared & 2.6125 & 0.2708 \\
\hline \multirow[t]{2}{*}{ ARCH Test } & F-statistic & 2.6472 & 0.0809 \\
\hline & Obs*R-squared & 5.0708 & 0.0792 \\
\hline
\end{tabular}

Notes: STOCK is stock market index, ER is exchange rates, CPI is consumer price index, IR is interest rate.

T-statistics is in brackets. $* * * ; * ; *$ indicates level of significance at $1 \%, 5 \%$, and $10 \%$.

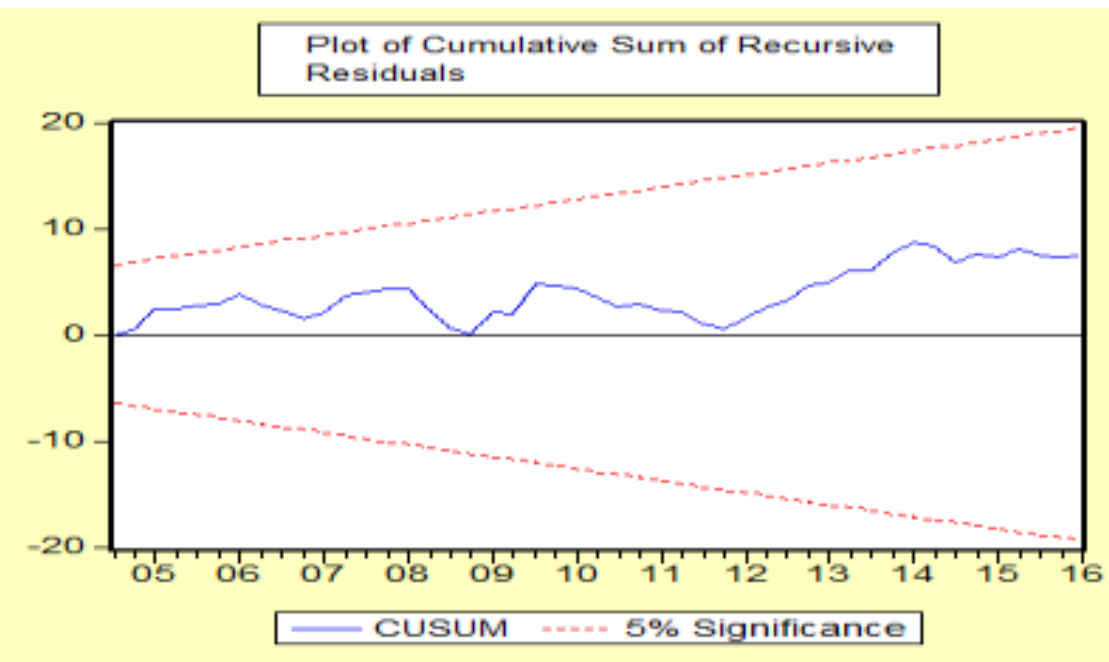

Figure1. Stability Plot of (CUSUM) for the model (F (STOCK /ER))

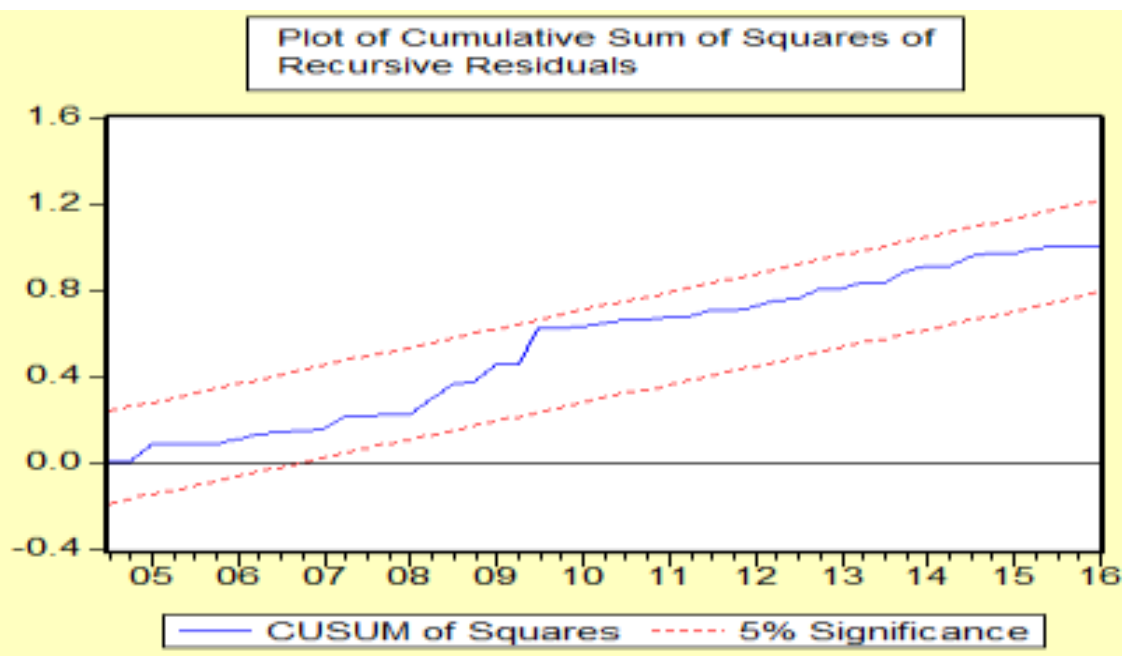

Figure2. Stability Plot of (CUSUMSQ) for the model (F (STOCK/ER))

\subsection{Granger Causality Analysis}

As all the data series are stationary at the first difference it would be safe to find short run relationship between variables of study. Study uses Granger causality analysis to find direction of causality between variables.

Table6. Granger Causality Test Results

\begin{tabular}{|l|l|l|}
\hline Null Hypothesis: & F-Statistic & Probability \\
\hline ER does not Granger Cause STOCK & 4.92 & 0.0112 \\
STOCK does not Granger Cause ER & 1.24 & 0.2988 \\
\hline IR does not Granger Cause STOCK & 1.19 & 0.3106 \\
STOCK does not Granger Cause IR & 0.15 & 0.8578 \\
\hline CPI does not Granger Cause STOCK & 8.13 & 0.0008 \\
\hline
\end{tabular}




\begin{tabular}{|c|c|c|}
\hline STOCK does not Granger Cause CPI & 0.33 & 0.7224 \\
\hline IR does not Granger Cause ER & 0.47 & 0.6249 \\
\hline ER does not Granger Cause IR & 2.08 & 0.1357 \\
\hline CPI does not Granger Cause ER & 12.42 & $4.2 \mathrm{E}-05$ \\
\hline ER does not Granger Cause CPI & 2.40 & 0.1010 \\
\hline CPI does not Granger Cause IR & 10.78 & 0.0001 \\
\hline IR does not Granger Cause CPI & 1.51 & 0.2304 \\
\hline
\end{tabular}

Table (6) represents results for Granger causality analysis. The Granger causality test observed unidirectional causality from exchange rates to stock market index with values (F-value $=4.92, \mathrm{P}$ value $=0.0112$ ). Study finds unidirectional causality between consumer price index and the stock market index with values $(\mathrm{F}$-value $=8.13, \mathrm{P}$-value $=0.0008)$. Granger causality analysis results find unidirectional causality between consumer price index and exchange rates with values (F-value $=$ 12.42 , P-value $=4.2 \mathrm{E}-05)$. Study finds unidirectional causality between consumer price index and interest rates with values $(\mathrm{F}$-value $=10.78, \mathrm{P}$-value $=0.0001)$.

\section{CONCLUSION}

The main objective of this paper is to investigate the long-run and short run relationship between stock market index and exchange rates along with two macro-economic variables interest rates and consumer price index for the period 2002:q1 to 2016:q1. Study uses autoregressive distributed lag (ARDL) modelling technique, error correction model, and Granger causality test. Study finds long run relationship between stock market index and exchange rates. But fails to find long run relationship between stock market index and exchange rates with interest rates and consumer price index. Moreover, the Granger causality analysis finds exchange rate Granger cause stock market index by showing unidirectional causality from exchange rates to stock market index. Results of the study suggest that there is a link between stock markets and foreign exchange markets. Investors can utilize information of one market to predict the behavior of other market. Findings of the study support traditional approach. Study suggests to utilize information of empirical findings by making exchange rate as a policy tool in order to boost foreign portfolio investment.

\section{REFERENCES}

[1] Yang SY, Doong SC. (2004). Price and volatility spillovers between stock prices and exchange rates: Empirical evidence from the G-7 countries. International Journal of Business and Economics, 3(2), 139153.

[2] Phylaktis, K and Ravazollo, F. (2005). Stock prices and exchange rate dynamics', Journal of International Money and Finance, 24(7), 1031-1053.

[3] Abdalla, ISA and Murinde, V. (1997). Exchange rate and Stock Price Interactions in Emerging Financial Markets: Evidence on India, Korea, Pakistan and the Philippines', Applied Financial Economics, 7, 25-35.

[4] Kanas, A. (2004). Volatility spillovers between stock returns and exchange rate changes: international evidence', Journal of Business Finance and Accounting, 27(3-4), 447-467.

[5] Morley, B., and Pentecost, E. J. (2000). Common trends and cycles in G-7 countries exchange rates and stock prices. Applied Economics Letters, 7(1), 7-10.

[6] Nieh, C. C., and Lee, C. F. (2002). Dynamic relationship between stock prices and exchange rates for G-7 countries. The Quarterly Review of Economics and Finance, 41(4), 477-490.

[7] Ratanapakorn, O., and Sharma, S. C. (2007). Dynamic analysis between the US stock returns and the macroeconomic variables. Applied Financial Economics, 17(5), 369-377.

[8] Azman-Saini, W. N. W., Habibullah, M. S., Law, S. H., and Dayang-Afizzah, A. M. (2006). Stock prices, exchange rates and causality in Malaysia: a note.

[9] Doong, S. C., Yang, S. Y., and Wang, A. T. (2005). The dynamic relationship and pricing of stocks and exchange rates: Empirical evidence from Asian emerging markets. Journal of American Academy of Business, 7(1), 118-123.

[10] Kim, K. H. (2003). Dollar exchange rate and stock price: evidence from multivariate cointegration and error correction model. Review of Financial economics, 12(3), 301-313.

[11] Patra, T., and Poshakwale, S. (2006). Economic variables and stock market returns: evidence from the Athens stock exchange. Applied Financial Economics, 16(13), 993-1005.

[12] Alagidede, P., Panagiotidis, T., and Zhang, X. (2011). Causal relationship between stock prices and exchange rates. The Journal of International Trade \& Economic Development, 20(1), 67-86. 
[13] Mishra, B., and Rahman, M. (1993). Joint efficiency of the US stock and foreign exchange markets: Evidence from cointegration. International Journal of Finance, 6, 640-650.

[14] Rahman, L., and Uddin, J. (2008). Relationship between Exchange Rates and Stock Prices: Evidence from Bangladesh. International Journal of Business and Management, 3(9), 52-57.

[15] Zhao, H. (2010). Dynamic relationship between exchange rate and stock price: Evidence from China. Research in International Business and Finance, 24(2), 103-112

[16] Muhammad, N., Rasheed, A., and Husain, F. (2002). Stock Prices and Exchange Rates: Are they Related? Evidence from South Asian Countries [with Comments]. The Pakistan Development Review, 535-550.

[17] Dornbusch, R., and Fischer, S. (1980). Exchange rates and the current account. American Economic Review, 70, 960-971.

[18] Branson, W. H. (1993). Macroeconomic determinants of real exchange risk. In R. J. Herring (Ed.), Managing foreign exchange risk. Cambridge, MA: Cambridge University Press.

[19] Frankel, J. A. (1983). Monetary and portfolio-balance models of exchange rate determination. In J. S. Bhandari, and B. H. Putnam (Eds.), Economic interdependence and flexible exchange rates. Cambridge, MA: MIT Press.

[20] Gavin, M. (1989). The stock market and exchange rate dynamics. Journal of International Money and Finance, 8, 181-200.

[21] Amare, T., and M. Mohsin (2000). Stock Prices and Exchange Rates in the Leading Asian Economies: Short Versus Long Run Dynamics. Singapore Economic Review 45:2, 165-181.

[22] Rahman, M., Rahman, M., and Mustafa, M. (2001). Long-run and short run dynamics between foreign exchange and stock markets: Evidence from Thailand and the Philippines. in (ed.) Research in Finance (pp. 245-257). Emerald Group Publishing Limited.

[23] Dumitrescu, S., and Horobet, A. (2009). On the Causal Relationship between Stock Prices and Exchange Rates: Evidence from Romania. Available at SSRN 1341703.

[24] Ooi, A. Y., Wafa, S. A. W. S. K., Lajuni, N., and Ghazali, M. F. (2009). Causality between exchange rates and stock prices: evidence from Malaysia and Thailand. International Journal of Business and Management, 4(3), 86.

[25] Johansen, S., and K. Juselius (1990) Maximum Likelihood Estimation and Inference on Cointegration with Application to the Demand for Money. Oxford Bulletin of Economics and Statistics 52, 169-210.

[26] Toda, H. Y., and Yamamoto, T. (1995). Statistical inference in vector autoregressions with possibly integrated processes. Journal of econometrics, 66(1), 225-250.

[27] Adjasi, C. K., Biekpe, N. B., and Osei, K. A. (2011). Stock prices and exchange rate dynamics in selected African countries: a bivariate analysis.African Journal of Economic and Management Studies, 2(2), 143164.

[28] Chen, S. W., and Chen, T. C. (2012). Untangling the non-linear causal nexus between exchange rates and stock prices: new evidence from the OECD countries. Journal of Economic Studies, 39(2), 231-259.

[29] Noman, A. M., Humayun Kabir, S., and Bashar, O. K. (2012). Causality between stock and foreign exchange markets in Bangladesh. Studies in Economics and Finance, 29(3), 174-186.

[30] Billah Dar, A., Shah, A., Bhanja, N., and Samantaraya, A. (2014). The relationship between stock prices and exchange rates in Asian markets: A wavelet based correlation and quantile regression approach. South Asian Journal of Global Business Research, 3(2), 209-224.

[31] Abdullah, M. N., Parvez, K., Tooheen, R. B., and Saha, J. (2015). Relation between Stock Prices and Exchange Rates: Evidence from South Asian Countries. International Review of Business Research Papers, 11(2).

[32] Engle, R. F., and C. W. J. Granger (1987) Co-integration and Error Correction: Representation, Estimation, and Testing. Econometrica 55, 251-276.

[33] Johansen, S. (1988) Statistical Analysis of Cointegrating Vectors. Journal of Economic Dynamic and Control 12, 231-254.

[34] Johansen, S. (1991) Estimation and Hypothesis Testing of Cointegrating Vectors in Gaussian Vector Autoregressive Models. Econometrica 59: (November), 1551- 1580.

[35] Phillips, P. C. B. and Hansen, B. E. (1990) Statistical Inference in Instrumental Variables Regression with I(1) Processes," Review of Economics Studies, 57, 99-125.

[36] Pesaran, M., and Shin,Y. (1999). An Autoregressive Lag Modeling Approach to Cointegration Analysis. In S. Strom. (ed) Econometrics and Economic Theory in 20th Century: The Ragnar Frisch centennial Symposium, Cambridge University Press, Cambridge. 
[37] Asterious, D. (2006). Applied econometrics: A modern approach using eviews and microfit, England: Palgrave Macmillan.

[38] Blin, M., and Ouattara, B. (2009). Foreign direct investment and economic growth in Mauritius: Evidence from bounds test cointegration. Économie internationale, (1), 47-61.

[39] Granger, C. W. (1969). Investigating causal relations by econometric models and cross-spectral methods. Econometrica: Journal of the Econometric Society, 424-438.

[40] Pesaran, M. Hasem, Yongcheol Shin and Richard J. Smith (2001)," Bounds testing approaches to the analysis of level relationships", Journal of Applied Econometrics, 16(3), 289- 326.

\section{AUTHORS' BIOGRAPHY}

Fahmida Laghari, is a $\mathrm{PhD}$ student at Business School of University of International Business and Economics (UIBE) Beijing, China.

Ye Chengang, PhD., is a professor at Business School of University of International Business and Economics (UIBE) Beijing, China.

Citation: Fahmida, Laghari and Ye Chengang "Are Stock Markets and Foreign Exchange Markets Cointegrated? An Empirical Analysis." International Journal of Managerial Studies and Research (IJMSR), vol 5, no. 12, 2017, pp. 1-10. doi:http://dx.doi.org/10.20431/2349-0349.0512001.

Copyright: (C) 2017 Authors. This is an open-access article distributed under the terms of the Creative Commons Attribution License, which permits unrestricted use, distribution, and reproduction in any medium, provided the original author and source are credited. 